\title{
The Economic Role of Tourism and the Dimension of the Touristic Phenomenon on a National and Global Scale
}

\author{
Florin Lucian Isac, „Aurel Vlaicu” University of Arad, Romania \\ Radu Cureteanu, „Aurel Vlaicu” University of Arad, Romania \\ Sergiu Rusu, ,Aurel Vlaicu” University of Arad, Romania
}

\begin{abstract}
Nowadays tourism represents a quite distinct field of human activity, a component of highest importance of the economic and social life for an ever larger number of countries on the globe. Tourism evolves constantly due to the changes occurring in contemporary civilization, its dynamics integrating in the general process of development.
\end{abstract}

\section{Keywords}

tourism, tourism industry, tourism destination

\section{JEL Codes: L 83, E 61}

Tourism plays a very important part in economy by its outstanding contribution to the diminishing of the rate of unemployment. The complexity of the tourist industry, the variety of the preferences and tastes of the touristic consumers, the necessity of personalizing and individualizing vacations, the reduced possibility of automating and mechanizing the operations turns the touristic field into a large labor force consumer. On the other hand, the numberless growth of persons undertaking trips, the extension of the travel distances, of the time afforded to holidays implicitly brings about the enlarging of those implied in the process of carrying out services to tourists.

World Travel and Tourism Council counted on 192 million people directly involved in the tourism business, that is $8 \%$ of the entire world labor force being employed in tourism on a global scale, that means that 1 of 12 persons is active in tourism. As to 2005, the same Bodies estimated the doubling in growth of tourism implied workers, reaching the amount of about 338 million people, thus turning tourism into the most extensive industry in the world.

\section{Why not to travel? Reasons:}

Some people refuse to undertake a trip from various reasons. Some of the most common ones are: "I cannot afford" or "I do not have time enough". However, more often these motifs are but ungrounded excuses uttered with a view of hiding the real questions a traveler might encounter: fear of the unknown, fear for flying by plane, lack of trusting a country whose language is unknown to him [Davidoff P.G., Davidoff D.S., Sales and Marketing for Travel and Tourism, National Publishers, 1983, pag.33]

I. Niţă and C. Niţă, undertaking a comparison with other fields of activity reveals the numberless advantages tourism offers:

- The VAT in tourism is by far higher than in other fields of activity, even because the import of raw materials in this area is insignificant;

- This branch is not an intensive energy consumer; 
- It allows the turning of several materials and human resources into foreign currency that cannot be exploited otherwise;

- It uses national raw materials on a large scale;

- The return course in tourism is favorable as comparable to other branches, as it is viewed as an invisible export, the price of the touristic products being no longer charged with packing expenses, customs taxes, insurances;

- Tourism involves directly and indirectly important consumptions of industrial products;

- Tourism assures the balanced development of all the zones in a country.

The main difference between tourism and other forms of recreation [Mak J., Tourism and the Economy, University of Hawai'i Press, 2004, pag.5] consists of the fact that the consumers need traveling in order to consume tourism. Recreation does not always imply traveling. Playing tennis or attending a theatre show are recreation activities, however the distance to reach the performance places is minimal. Such a person does not leave home for a long period of time. But, traveling implies the way from home to temporarily use another residence in a quite different location.

The outstanding importance of tourism within the national economy resides in its nature of being an economic branch of interface and synthesis due to the diversity of the branches incorporated in the content of the tourism industry services. The links between tourism and the other economic branches are complex and extensive, taking different forms, manifesting directly or indirectly, periodically or permanent, on the horizontal or vertical plan.

For instance, the unfolding of the tourist activity require inputs from other economic branches: food processing industry, agriculture, constructions industry, energetics, machine building industry. The direct links refer to telecommunications, transportation, art and culture. This is what reveals the important position in the structure of the economic mechanism and its active role in human society's economic development and modernization. Contemporary tourism proves to be a vast industry in full and rapid extension, while the main reasons of this explosion are given by the specific phenomena of the end of the 20-th century: the growth of people's welfare, the ample demographic changes, the additional time afforded to travels, the rising mobility of the people, the development of the transport means, the up-to-date technology applied on all levels and, last but not least, the maturation of the tourist industry. [Bosselman F., Peterson C., McCarthy C., Managing Tourism Growth, Issues and Applications, Island Press, 1999, pag. 1]

There took place great changes of the touristic products and their mass consumption. Thus, we may identify four distinct steps [Williams A., Shaw G., Tourism \& Economic Development, European Experiences, John Wiley \& Sons Ltd., 1998, pag. 3], each of them being characterized by various forms of transport or substance of the social access to tourism:

1. on a first stage, tourism was socially forced,tourists coming especially from rich zones of northern Europe to Italy or Greece, constituting a period anterior to the development of railroad transport;

2. on a second stage, beginning with the 19-th century, the middle class from rich countries undertook romantic travels to non-industrial Europe, so that the area of the Mediteranean Sea become the most appreciated world vacation area;

3. on a third stage, there emerged the modern mass tourism;

4. on a fourth stage: the green tourism that revitalized the non-industrialized zones from the North and Centre of Europe

Organized tourism stretched as soon as tourism manifested as a mass phenomenon. [Isac F., Rusu S., Management în turism, Editura Mirton, Timişoara, 2007, pag. 35] The economic development from the whole world, corresponding to the total or partial elimination of the commercial barriers, the extension and globalization of world economy, contributed to the creation of more favorable conditions to both the international and national tourism, conditions which were influenced even by the approach to the touristic circuit of new zones, as well as by the embettering of life quality. Tourism is an important income source for 
towns, zones or countries. [Kaser K., Freeman J., Hospitality Marketing, SouthWestern/Thomson Learning, 2002, pag. 42]

The touristic system is composed of four integrated parts: [Lumdson L., Tourism Marketing, International Thomson Business Press, 1997, pag. 9.]

- the market- referring to the necessity of making acquaintance with consumer's behavior manifested under social and cultural restrictions;

- the travel - referring especially to travel segments, visitor flux and their features

- the destination - based upon touristic attractions, but also upon sales policies applied in the zone

- marketing - implying marketing planning and the use of marketing tools

The influence upon tourism is manifested from multiple and many-sided directions evolving under the incidence of numberless factors, quite different as to their role and nature. The factors of influence, like the economic growth, free time or geographic mutations affects somehow, in various proportions, the entire branch of tourism, turning the accurate observation of the influence of each individual factor quite difficult.

The stages of the development of the touristic destinations: [Laws E., Tourism Marketing, Service and Quality Management Perspectives, Stanley Thornes Publishers Ltd., 1991, pag. 134]

- the pre-tourism : business and personal travels

effects: minimal impact upon communities

- the proper travelling: the ever rising frequency of independent tourists

effects: business opportunities are recognized by undertakers; the local population becomes either hospitable or hostile to visitors

- the mass tourism: tourist groups traveling regularly

effects: natives' occupations greatly depend on tourism and investments in it

- the tourism management: recognition of tourism as areal industry

effects: development of the infrastructure, planned growth, protection measures for the environment.

\section{Bibliography:}

1. Bosselman F., Peterson C., McCarthy C., Managing Tourism Growth, Issues and Applications, Island Press, 1999,

2. Davidoff P.G., Davidoff D.S., Sales and Marketing for Travel and Tourism, National Publishers, 1983,

3. Isac F., Rusu S., Management în turism, Ed. Mirton, Timişoara, 2007,

4. Kaser K., Freeman J., Hospitality Marketing, South-Western/Thomson Learning, 2002,

5. Lumdson L., Tourism Marketing, International Thomson Business Press, 1997,

6. Mak J., Tourism and the Economy, University of Hawai'i Press, 2004,

7. Rusu S. Isac. F., Turism rural şi ecoturism, Ed. Universității “Aurel Vlaicu”, 2009,

8. Williams A., Shaw G., Tourism \& Economic Development, European Experiences, John Wiley \& Sons Ltd., 1998. 